\title{
A QUANTITATIVE ANALYSIS OF FORESTRY SECTOR CONTRIBUTION FOR THE INCREASE OF MINAS GERAIS MUNICIPALITIES REVENUES ${ }^{1}$
}

\author{
Gabriel Browne de Deus Ribeiro ${ }^{2 *}$, Crismeire Isbaex $^{2}$ and Sebastião Renato Valverde ${ }^{3}$
}

\footnotetext{
${ }^{1}$ Received on 10.04.2017 accepted for publication on 14.05.2018.

${ }^{2}$ Universidade Federal de Viçosa, Programa de Pós-Graduação em Ciência Florestal, Viçosa, MG-Brasil. E-mail: <gabrielbrowne@gmail.com> and <engisbaex@gmail.com>.

${ }^{3}$ Universidade Federal de Viçosa, Departamento de Engenharia Florestal, Viçosa, MG-Brasil. E-mail: <valverde@ufv.br>.

*Corresponding author.
}

\begin{abstract}
The main objective of this study was to analyze the contribution of forestry sector for the increase of revenues of Minas Gerais state municipalities during the period 2008-2013, using appropriate statistical analysis. Forestry is an important economic activity of this state, mainly through reforestation of Eucalyptus and Pinus genres. According to the work's hypotheses, statistical procedures were performed comparing groups of municipalities with $5 \%$ and $10 \%$ or more of their area destined to forest plantations. The main results showed that: for 134 municipalities with 5\% or more of forestry area, a linear relationship was observed between the Production Value of Silviculture and the collection of Tax on Rural Territorial Property (ITR), with the Gross Added Value of Agriculture in the period 2008-2013. Greater participation of forestry revenues on the Gross Domestic Product (GDP) of those municipalities was also observed. For 57 municipalities with $10 \%$ or more of forestry area, there was an improvement in the Tax and Economic Development Index (IDTE). Therefore, it can be affirmed that silviculture caused positive impacts for taxes collection and revenues related to the productive sector for the municipalities with larger area of forest plantations.
\end{abstract}

Keywords: Planted forests; Mann-Whitney tests; Multiple regression.

\section{UMA ANALISE QUANTITATIVA DA CONTRIBUIÇÃO DA SILVICULTURA PARA O AUMENTO DAS RECEITAS DOS MUNICÍPIOS DO ESTADO DE MINAS GERAIS}

\begin{abstract}
RESUMO - O objetivo central do trabalho foi analisar a contribuição do setor da silvicultura no aumento das receitas dos municípios do estado de Minas Gerais, no período 2008-2013, utilizando-se análises estatísticas apropriadas. A silvicultura é uma importante atividade econômica deste estado, principalmente o reflorestamento de espécies do gênero Eucalyptus e Pinus. De acordo com as hipóteses de trabalho, foram realizados procedimentos estatísticos comparando grupos de municipios com $5 \%$ e $10 \%$ ou mais de sua área destinada a plantios florestais. Os principais resultados demonstraram que: para os 134 municípios com 5\% ou mais de área destinada a plantios florestais, existiu relação linear entre o Valor de Produção da Silvicultura (VPS) e a arrecadação do Imposto sobre a Propriedade Territorial Rural (ITR), com o Valor Adicionado Bruto da Agropecuária no período 2008-2013. Também foi observada maior participação das receitas provenientes da silvicultura sobre o Produto Interno Bruto (PIB) municipal destas cidades. Para os 57 municipios com 10\% ou mais de área destinada à silvicultura, houve melhora no Índice de Desenvolvimento Tributário e Econômico (IDTE). Portanto, pode-se afirmar que a atividade da silvicultura causou impactos positivos para a arrecadação de tributos e receitas vinculadas ao setor produtivo dos municípios com maior área de plantios florestais.

Palavras-Chave: Árvores plantadas; Teste de Mann-Whitney; Regressão múltipla.
\end{abstract}




\section{INTRODUCTION}

Planted forests are an alternative to meet wood growing demand, provide environmental gains and, consequently, sustainable economic development (Zhang et al., 2015).

For the state of Minas Gerais (Southeastern Brazil), planted forest sector constitutes an important activity largely through reforestation of genera Eucalyptus and Pinus - mainly eucalyptus. This activity contributes with revenues and employment for regional economy as well as reduces pressure on native forests, playing a significant role to the carbon absorption from the atmosphere (Valverde et al., 2012).

By the end of 2015, about $25 \%$ of Brazil's planted forests were in Minas Gerais (1.88 million hectares / $98 \%$ eucalyptus), according with data from the Brazilian Institute of Geography and Statistics (IBGE, 2015) which made the state the largest forest producer in the country. The main consumers and also producers of planted forests are the large metallurgical metal park, the growing pulp industry and, to a lesser extent, wood panels industry. These forest companies have formed their own forest biomass supply over the years, holding large amounts of land and plantations (Vital et al., 2013).

Only in 2015, planted forest sector generated 540 thousand new jobs and presented GDP of R \$ 69.1 billion in the country (IBÁ, 2016). In the same year, gross production value of silviculture reached $\mathrm{R} \$ 13.7$ billion in Brazil and R\$3.2 billion in Minas Gerais (23.2\% of the country), which demonstrates the importance of this state for the national forest sector.

Table 1 presents the evolution of gross production value of silviculture from 2008 to 2013 - total and by product. It can be noted the weight of Minas Gerais participating with $1 / 4$ to $1 / 5$ of the total production value of Brazilian silviculture, with a predominance of charcoal from eucalyptus plantations.

In spite of forestry is an economic activity that occupies considerable territorial space, and represents an important labor force for Minas Gerais, there are few studies about the contribution of this sector to public finance indicators. Possibly due to the scarcity of municipal forestry data, as a consequence of lesser degree of organization and governance of forest producers (Valverde et al., 2014).

In Almeida et al. (2008), Gurgel et al. (2009) and Machado (2004) studies, the contribution of planted forest sector was evaluated through the analysis of the decennial variation of Municipal Human Development Index (IDHM).

For the extreme southern region of Bahia, Almeida et al. (2008) concluded that although there were GDP and IDHM growth for the surveyed municipalities of this region - recognized by the strong participation of pulp industry - few socioeconomic improvements were observed from forestry sector investments. In this line, Gurgel et al. (2009) commented that the economic expansion of logging is usually accompanied by an improvement in the IDHM in the short term, as observed in the Amazon region and in regions with forestry vocation. However, the unsustainable exploitation, without monitoring and no social promotion polices might lead to rapid economic decline and exhaustion of forest resources and soil fertility.

Machado (2004), on the other hand, showed that the impact of silviculture activities on municipalities with forest plantations in several regions of Brazil led to an increase in employment and income generation, and increase in IDHM for those municipalities.

Nevertheless, this study understands that the contribution of the sector in terms of improvement in revenues and municipal income is still few explored in a quantitative perspective, based on statistical procedures.

The objective of this work, therefore, is to evaluate - using appropriate statistical analysis - forestry sector contribution on public finance of Minas Gerais municipalities, seeking to understand sector association with tax collection, gross added value and finance indexes.

\section{MATERIALAND METHODS}

\subsection{Data description}

Fiscal and accounting annual data was collected for the period 2008-2013, for all 853 municipalities of Minas Gerais. Database was formed by the following secondary quantitative data: Municipal revenues from tax collection: ICMS (Tax on Circulation of Goods and Services), ITR (Tax on Rural Territorial Property) and ISSQN (Tax on Services of any Nature). Gross Added Value of industry and services (designated as GAV IndServ), and Gross Added Value of agriculture (GAV Agri), all data in Brazilian Reais. Production Value of Silviculture (designated as PVS), which comprises the

Revista Árvore. 2018;42(3):e420303

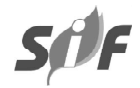


Table 1 - Brazil and MG comparative of Production Value of Silviculture by product (2008-2013). Tabela 1-Comparativo Brasil e MG do Valor de Produção da Silvicultura por produto (2008-2013).

\begin{tabular}{|c|c|c|c|c|c|c|c|}
\hline $\begin{array}{c}\text { Gross Production } \\
\text { Value (R\$/million) }\end{array}$ & Reference & 2008 & 2009 & 2010 & 2011 & 2012 & 2013 \\
\hline \multirow{3}{*}{ Total } & Brazil & $8,788.99$ & $9,010.96$ & $10,700.90$ & $13,149.32$ & $14,185.89$ & $14,149.82$ \\
\hline & MG & $2,259.11$ & $1,735.55$ & $2,024.66$ & $2,566.01$ & $3,461.08$ & $3,282.84$ \\
\hline & MG/Brazil (\%) & $25.70 \%$ & $19.26 \%$ & $18.92 \%$ & $19.51 \%$ & $24.40 \%$ & $23.20 \%$ \\
\hline \multirow{3}{*}{ Charcoal } & Brazil & $2,024.01$ & $1,494.75$ & $1,685.92$ & $2,181.58$ & $2,403.49$ & $2,627.46$ \\
\hline & MG & $1,657.50$ & $1,209.86$ & $1,362.66$ & $1,806.29$ & $2,003.26$ & $2,153.81$ \\
\hline & MG/Brazil (\%) & $81.89 \%$ & $80.94 \%$ & $80.83 \%$ & $82.80 \%$ & $83.35 \%$ & $81.97 \%$ \\
\hline \multirow{3}{*}{ Firewood } & Brazil & $1,258.01$ & $1,344.23$ & $1,629.23$ & $1,953.78$ & $2,236.57$ & $2,322.35$ \\
\hline & MG & 155.81 & 127.12 & 170.38 & 181.99 & 247.96 & 214.46 \\
\hline & MG/Brazil (\%) & $12.39 \%$ & $9.46 \%$ & $10.46 \%$ & $9.31 \%$ & $11.09 \%$ & $9.23 \%$ \\
\hline \multirow{3}{*}{ Timber } & Brazil & $5,423.83$ & $6,082.63$ & $7,246.07$ & $8,862.08$ & $9,412.76$ & $9,059.08$ \\
\hline & MG & 437.12 & 389.33 & 477.08 & 558.77 & $1,197.86$ & 888.53 \\
\hline & MG/Brazil (\%) & $8.06 \%$ & $6.40 \%$ & $6.58 \%$ & $6.31 \%$ & $12.73 \%$ & $9.81 \%$ \\
\hline
\end{tabular}

Source: Adapted from IBGE, 2015. MG = Minas Gerais state.

total production value of charcoal, firewood, timber (for paper, pulp and other purposes), in Brazilian Reais. Municipal area destined to eucalyptus and pinus forest production, in hectares, covering the average of the period 2013-2014; and relative area for forestry (forestry area / total municipal area).

For statistical analysis, the Tax and Economic Development Index (IDTE) of 2013 was used, as it will be explained later, aiming to comprehend if there is association between the area of planted forests and the income measured by the IDTE for the municipalities.

IDTE is a relevant municipal finance index created by João Pinheiro Foundation in 1998, which is the basis of IMRS index (Social Responsibility Index of Minas Gerais state). This index is intended to make a reading about economic conditions and the stage of development of municipalities regarding its revenues structure. Although it does not measure the self-financing capacity of the municipal administration, it still provides some elements for it (Oliveira and Biondini, 2013). IDTE index is formed by the contribution of own tax revenues and by revenues linked to productive activity of the municipalities.

As commented by Rezende et al. (2005) and Hummel (2013), there are several taxes on forest activity, covering from timber production (planting and harvesting) to the company yard and industrialization of timber products. These incidental taxes are divided into taxation, social contributions and taxes. Eucalyptus and pinus forest plantations have the same tax structure as of any other exotic forest planting (such as African mahogany, Australian cedar, Acacia, etc.).
ICMS and ISSQN are the taxes that most affect the productive chain of the sector, especially in planting and harvesting phases. ITR may also have impact, but it depends on the size and degree of utilization of the rural property. Other taxes, such as IPI and social contributions, might have presence, depending on the size of the forest company and its insertion as an exporter (Hummel, 2013).

Taxes are those that have the largest share of the total costs of timber production, which can reach more than $30 \%$ of the costs (Hummel, 2013). For this study, only the impacts of ICMS, ISSQN and ITR taxes were measured.

The analyzed period (2008-2013) corresponds with the cutting cycle of eucalyptus and pinus, which in Minas Gerais is predominantly from five to seven years for the products that are the basis of the production value of silviculture - charcoal and timber. Then, six-year data was collected to measure with better quality and robustness the impact of forestry sector on public finance. Annual financial data was adjusted for the average inflation of each year aiming to work with an average value of the period (IPCA basis - Brazilian Consumer Price Index).

In addition, all analyzed variables were divided by municipal GDP or by the municipal population (per capita), seeking to convert all data into indices. For example: 2008-2013 production value of silviculture divided by 2008-2013 municipal GDP, resulting in PVS/ GDP variable, in percentage; and PVS/pop in per capita factor, which may aggregate in the analysis human development and life quality questions (Bresser-Pereira, 2006). 
Forestry data was obtained from IBGE, accounting variables data of municipalities from FINBRA - database of the National Treasury and from IMRS.

\subsection{Statistical procedures - U-test for independent samples}

As the statistical test is an inferential procedure that uses sample data, the objective of this work's procedures was to infer for the population (reality) based on sample evidences.

Thus, two cuts of municipalities were determined in order to identify statistically significant differences in some variables, according to the following hypotheses:

Hypothesis 1: For municipalities with a minimum of $10 \%$ of area devoted to forestry, IDTE index will be, on average, larger when compared to municipalities with less than $10 \%$ of forestry area. The objective is to identify if there is an association between the greater area of planted forests and the improvement of municipalities revenue structure, covered by IDTE.

Hypothesis 2: For municipalities with a minimum of $5 \%$ of forestry area (larger sample), the production value of silviculture over GDP (and over per capita) will be, on average, higher when compared to municipalities with less than $5 \%$ of area with forest plantations. The objective is to understand if there is an association between the greater area of planted forests and the larger participation of the forest sector in municipal and per capita GDP. It is important to emphasize that this association may not be clear because of the difficulty in measuring the participation of many independent forest producers and the lack of regulation in the forest activity (Valverde et al., 2014). Cut values of $5 \%$ and $10 \%$ of planted area were established by the authors on ad hoc basis - built on their experience.

Before performing the tests, the first step was to carry out a data exploratory analysis (Table 2 ) to evaluate the homogeneity of variances between the groups and also to evaluate if the variables IDTE, PVS/GDP and $\mathrm{PVS} /$ pop in the groups can be considered as originating of normal populations. It is important because the Student's $t$-test, although robust to the assumption of normality of the data, is sensitive to the heterogeneity of variances (Harnett and Murphy, 1986; Pestana and Gageiro, 2008).

When it is not possible to presume that the assumptions that validate a parametric test are not

Revista Árvore. 2018;42(3):e420303 met, an alternative is the use of methods that do not require, at first, any assumption about the distributional population form. These are called non-parametric methods. In general, it is recognized that parametric tests have greater power to equivalent non-parametric tests, when assumptions of the test are met. Power of the test is the probability of correctly rejecting the null hypothesis (Maroco, 2007). Therefore, the use of non-parametric tests is justified when the conditions of application of parametric tests are not validated.

Mann-Whitney test (U-test) is a non-parametric method alternative to the Student's $t$-test for two independent samples (Stokes et al., 2000). Some studies, such as Silva et al. (2011), Massardi et al. (2014) and Ioannides and Overman (2003) used Mann-Whitney test to evaluate hypotheses related to the financial performance of different groups of municipalities.

After the exploratory analysis, the normality hypothesis of IDTE, PVS/GDP and PVS/pop variables was tested using Kolmogorov-Smirnov (K-S) test, with Lilliefors correction. Homogeneity of variances was verified by Levene's test.

Then, based on the results obtained from the variables normality tests, Mann Whitney test was used to compare two independent samples, in order to evaluate if the two groups of municipalities of each hypothesis have the same mean values for each analyzed variable. All statistical analyses were implemented in SPSS Software (v.22; IBM SPSS Statistics), according with Maroco (2007) and 5\% was adopted as level of significance.

\subsection{Statistical procedures - multiple linear regression analysis}

A multiple linear regression model is a statistical model which function is based on the hypothesis that a quantitative variable ( $Y$ dependent) is linearly related with two or more explanatory variables ( $X$ 's independent), but the relationship between them is not exact, and is subject to individual variations (Gujarati et al., 2011). The objective of the analysis is to explain the behavior of Y dependent variable from $X$ 's independent variables, without assuming a causal association between them (Pestana and Gageiro, 2008).

In summary, regression analysis is divided into two stages, the first one is the model adjustment, when regression coefficients are estimated (model parameters 
determination), and in the second step, hypothesis tests are performed regarding the parameters and the adequacy (quality) of the adjustment is verified (Hair et al., 2005; Maroco, 2007).

For this work, a multiple linear regression model was used, where the $Y$ dependent variable was defined as the Gross Added Value of Agriculture by GDP (GAV agri/GDP). Gross Added Value of Agriculture, as described by IPEADATA is the value that the farming activity (agriculture and cattle production) adds to goods and services consumed in its production process, representing the contribution to gross domestic product, obtained by the difference between the production value and the absorbed intermediate consumption by farming activities.

The following four variables were considered as explanatory: $\mathrm{X}_{1}=\mathrm{PVS} / \mathrm{GDP}, \mathrm{X}_{2}=$ Planted Area/GDP, $\mathrm{X}_{3}=\mathrm{ITR} / \mathrm{GDP}$, and $\mathrm{X}_{4}=\mathrm{GAV}$ is/GDP (industry and services). General format of the multiple linear regression model is:Eq1

$$
Y_{i}=\beta_{0}+\beta_{1} X_{1 i}+\beta_{2} X_{2 i}+\cdots+\beta_{k} X_{k i}+u_{i}
$$

In which $Y$ is the dependent variable, $X_{\mathrm{k}}$ are the independent variables (regressors), $u$ is the unobservable random error, which reflects, in addition to the effects of all other variables not considered in the model, the measurement errors and natural variation of $Y$; $i$ is the indicator of the $i$-th observation (varies from 1 to $n$ ). Moreover, $\beta_{0}$ is the intercept, which can be interpreted as the mean effect on $Y$ of all excluded-variables from the model, and $\beta_{1}$ to $\beta_{\mathrm{k}}$ are partial regression coefficients (model parameters).

An important measure of the model quality dataadjustment is provided by $\mathrm{R}^{2}$, the coefficient of determination (Gujarati et al., 2011). $\mathrm{R}^{2}$ estimates the proportion of variability observed in $Y$ that was explained by the regression model in the $X$ 's dependent variables, or, in other words, the size of independent variables effect on dependent variable (Maroco, 2007). Its value varies from zero to one, where the closer to zero, the lower the quality of the adjustment; and the closer to one, the better it will be (Pestana and Gageiro, 2008). For exact sciences, the authors understand that a $\mathrm{R}^{2}>0.9$ is accepted as good adjustment, while for economic and social sciences, $R^{2}>0.5$ is already considered acceptable. For this work, an adjusted $\mathrm{R}^{2}$ above 0.5 was adopted as acceptable - or the model well adjusted to the data.
In order to test the proposed hypothesis, Pearson correlations (bivariate and partial) between all pairs of variables were estimated and the significance was evaluated, aiming to understand significant correlation values.

Regression analysis was performed following the steps proposed by Pestana and Gageiro (2008). Regression and correlation analyses were implemented in SPSS Software (v.22; IBM SPSS Statistics).

\section{RESULTS}

For Hypothesis 1, 57 municipalities from Minas Gerais have a minimum of $10 \%$ of forestry area; the remaining (796 municipalities) have less than $10 \%$. Through K-S test with Lilliefors correction, the level of significance of 0.00 (p-value) led to the rejection of the normality hypothesis of IDTE distribution. Therefore, the non-parametric Mann-Whitney test for independent samples (U-test) was preferred to compare mean values of the two groups of municipalities.

U-test results showed that the 57 municipalities with $10 \%$ or more of forestry area have an average IDTE of $32.6 \%$, while the remaining have an average IDTE of $26.9 \%$. These results allow this work to infer that the difference of the mean IDTEs of the two groups of municipalities are statistically significant ( $p$-value $=0.014)$.

Regarding Hypothesis 2, from the 853 municipalities of the state, 134 have $5 \%$ or more, and the remaining (719 municipalities) have less than $5 \%$ of their total area for forestry, and 79 municipalities without any planted forests. For the variable under analysis (PVS/GDP), K-S test with Lilliefors correction ( $p$-value $=0.00$ ) rejected the normality hypothesis and Levene's test rejected the homogeneity of variances hypothesis - again U-test was preferred.

For the 134 municipalities with 5\% or more of forestry area, the average PVS/GDP was $9.7 \%$. That is, on average almost $10 \%$ of the GDP of these cities comes from forestry, while for the remaining 719 cities, on average only $1.2 \%$ of their GDP is derived from forestry, and these values are statistically different $(p$-value $=0.00$ ). These results corroborate with the association between forest plantations and greater participation of forest production revenues in municipal GDP.

$\mathrm{PVS} /$ pop variable also presented in K-S test with Lilliefors correction $\mathrm{p}$-value $=0.00$, rejecting the normality 
hypothesis, which made the U-test preferable to the $t$ test. In addition, the Levene's test rejected the homogeneity of variances hypothesis. Data analysis showed that for the 134 municipalities with $5 \%$ or more of forestry area, the average PVS per capita was 1,102 Reais /inhabitant, while in the remaining 719 cities, on average, only 122 Reais /inhabitant comes from silviculture revenues. Statistically different values were observed again in U-test ( $p$-value $=0.00$ ). A summary of the results is presented in Table 2 .

For the analysis by multiple linear regression, first it was verified by means of partial correlation estimates, which variables have association and explain variations in the dependent variable Gross Added Value of Agriculture by GDP(GAV Agri/GDP) for 134 municipalities with $5 \%$ or more of forestry area. A summary of the results is presented in Table 3.

It was observed that PVS/GDP, Planted Area/GDP, ITR/GDP, and GAV IndServ/GDP (industry and services) were the main significant explanatory variables, even after analyzing the partial correlation controlled by the variable with the highest correlation.

Multiple linear regression analysis resulted in the adjusted model with GAV Agri as dependent variable and PVS/GDP, GAV IndServ/GDP and ITR/GDP as independent variables, presented below:

$$
\begin{aligned}
& \frac{G A V \text { Agri }}{G D P}=-1.201+0.419 \times \frac{\mathrm{PVS}}{\mathrm{GDP}}+ \\
& 1.433 \times \frac{\mathrm{GAV} \text { IndServ }}{\mathrm{GDP}}+70.368 \times \frac{\mathrm{ITR}}{\mathrm{GDP}}
\end{aligned}
$$

The explanatory variable Planted Area/GDP was not included in the model because it was not significant at $5 \%$, despite having a positive and significant correlation with the dependent variable in Pearson's correlation test. The other taxes and variables tested were not significant to the dependent variable and, therefore, did not enter the model.

In this model, the quality of the adjustment measured by the coefficient of determination was 0.52 , which means that $52.0 \%$ of the changes in Gross Added Value of Agriculture by GDP are explained by the linear relationship between the explanatory variables (PVS/ GDP, GAV IndServ/GDP and ITR/GDP). The remaining variation $(48.0 \%)$ is explained by other factors not specified and that are included in the error term. The $\mathrm{R}^{2}$ value greater than or equal to 0.5 is already considered acceptable in economic and social sciences, as already explained (Maroco, 2007). F test was significant at least $1 \%$, and the variables (coefficients) were also significant at least $1 \%$. The summary of results is presented in Table 4.

\section{DISCUSSION}

Statistical analysis indicates that municipalities with the largest forestry area (10\% or more) have a higher average IDTE index. Given that IDTE is formed by the contribution of own tax revenues and incomes from transfers linked to the productive activity of the district, it is suggested that forestry contributed to their revenue structure in the period 2008-2013, being associated with the highest tax collection and revenues linked to its production, which meets the initial expectations proposed by this work.

Comparisons between mean production values of silviculture by GDP also resulted in statistically different values, corroborating with the hypothesis that municipalities with greater area destined to forest plantations have bigger participation of the sector in their GDP. The association between planted area and silviculture revenues participation in the per capita

Table 2 - Summary of Kolmogorov-Smirnov (K-S) and Mann-Whitney test results.

\begin{tabular}{|c|c|c|c|c|c|c|c|}
\hline \multicolumn{2}{|c|}{$\begin{array}{l}\text { Variables /Planted } \\
\text { area by municipal area }\end{array}$} & $\begin{array}{c}\mathrm{N} \\
\text { (municipalities) }\end{array}$ & Mean & $\begin{array}{c}\text { Standard } \\
\text { deviation }\end{array}$ & $\begin{array}{l}\text { Coefficient of } \\
\text { variation }(\mathrm{CV})\end{array}$ & $\begin{array}{l}\text { K-S test } \\
\text { (p-value) }\end{array}$ & $\begin{array}{c}\text { U test } \\
\text { (p- value) }\end{array}$ \\
\hline \multirow[t]{2}{*}{ IDTE } & $<10 \%$ & 796 & $26.99 \%$ & $16.59 \%$ & $61.5 \%$ & 0.000 & 0.014 \\
\hline & $\geq 10 \%$ & 57 & $32.60 \%$ & $19.43 \%$ & $59.6 \%$ & & \\
\hline \multirow[t]{2}{*}{ PVS/GDP } & $<5 \%$ & 719 & $1.20 \%$ & $4.05 \%$ & $336.2 \%$ & 0.000 & 0.000 \\
\hline & $\geq 5 \%$ & 134 & $9.70 \%$ & $13.74 \%$ & $141.7 \%$ & & \\
\hline \multirow[t]{2}{*}{ PVS/pop } & $<5 \%$ & 719 & $\mathrm{R} \$ 121.68 /$ pop & $\mathrm{R} \$ 479.15$ /pop & $393.8 \%$ & 0.000 & 0.000 \\
\hline & $\geq 5 \%$ & 134 & $\mathrm{R} \$ 1,102.13 /$ pop & $\mathrm{R} \$ 1,950.90 /$ pop & $177.0 \%$ & & \\
\hline
\end{tabular}

Tabela 2 - Resumo dos resultados dos testes Kolmogorov-Smirnov (K-S) e Mann-Whitney (U).

Source: research results; pop $=$ municipal population.

Revista Árvore. 2018;42(3):e420303 
Table 3 - Correlations between the variables (Pearson test).

Tabela 3 - Correlações entre as variáveis (Teste de Pearson).

\begin{tabular}{|c|c|c|c|c|c|c|}
\hline \multicolumn{2}{|c|}{ Variables / Correlations } & GAV Agri/GDP & PVS/GDP & Planted Area/GDP & GAV/GDP & ITR/GDP \\
\hline \multirow{5}{*}{ Pearson correlation } & GAV Agri/GDP & 1.000 & 0.563 & 0.470 & 0.523 & 0.419 \\
\hline & PVS/GDP & 0.563 & 1.000 & 0.633 & 0.247 & 0.311 \\
\hline & Planted Area/GDP & 0.470 & 0.633 & 1.000 & 0.362 & 0.344 \\
\hline & GAV IndServ/GDP & 0.523 & 0.247 & 0.362 & 1.000 & 0.200 \\
\hline & ITR/GDP & 0.419 & 0.311 & 0.344 & 0.200 & 1.000 \\
\hline \multirow{5}{*}{ Significance } & GAV Agri/GDP & - & 0.000 & 0.000 & 0.000 & 0.000 \\
\hline & PVS/GDP & 0.000 & - & 0.000 & 0.002 & 0.000 \\
\hline & Planted Area/GDP & 0.000 & 0.000 & - & 0.000 & 0.000 \\
\hline & GAV IndServ/GDP & 0.000 & 0.002 & 0.000 & - & 0.010 \\
\hline & ITR/GDP & 0.000 & 0.000 & 0.000 & 0.010 & - \\
\hline
\end{tabular}

Source: research results.

Table 4 - Multiple Linear Regression.

Tabela 4-Regressão Linear Múltipla.

\begin{tabular}{|c|c|c|c|c|c|c|c|}
\hline \multirow{2}{*}{ Variables } & \multicolumn{2}{|c|}{$\begin{array}{c}\text { Non-standardized } \\
\text { coefficients }\end{array}$} & \multirow{2}{*}{$\begin{array}{c}\text { Standardized } \\
\text { coefficients } \\
\text { Beta }\end{array}$} & \multirow{2}{*}{$t$ statistic } & \multirow{2}{*}{ Sig. } & \multicolumn{2}{|c|}{ Collinearity statistics } \\
\hline & $\mathrm{B}$ & Stand. error & & & & Tolerance & VIF \\
\hline (Constant) & -1.205 & 0.224 & - & -5.369 & 0.000 & & \\
\hline PVS/GDP & 0.419 & 0.068 & 0.401 & 6.119 & 0.000 & 0.868 & 1.153 \\
\hline GAV/GDP & 1.433 & 0.239 & 0.380 & 5.989 & 0.000 & 0.922 & 1.085 \\
\hline ITR/GDP & 70.368 & 20.894 & 0.218 & 3.368 & 0.001 & 0.887 & 1.128 \\
\hline \multicolumn{3}{|c|}{ Observations } & \multicolumn{3}{|c|}{134} & & \\
\hline \multicolumn{3}{|l|}{$\mathrm{R}^{2}$} & \multicolumn{3}{|c|}{0.520} & & \\
\hline \multicolumn{3}{|c|}{ F Statistic (ANOVA) } & \multicolumn{3}{|c|}{46.221} & & \\
\hline \multicolumn{3}{|c|}{ Durbin-Watson Statistic } & \multicolumn{3}{|c|}{2.185} & & \\
\hline
\end{tabular}

Source: research results. GAV/GDP $=$ Gross Added Value from Industry and Services/Gross Domestic Product $($ district $)$. VIF $=$ Variance inflation factor

factor of these municipalities was also significant, where the group of 134 municipalities presented higher PVS/GDP and average PVS per capita, and consequently, greater contribution of silviculture revenues by GDP and per capita.

In summary, the three Mann-Whitney tests applied to the independent samples showed that there is a differentiation between the municipalities that have larger forestry area and those with smaller area. The tests also showed an association between the presence of silvicultural activity and improvement in revenue structure (IDTE), greater participation of the activity in the GDP, and in the per capita factor. In addition, all the tests led to results that corroborate the initial expectations, where municipalities with greater area destined to forest plantations have larger impact of the sector on municipal finances and on finance index IDTE.

Regarding the adjusted regression model, for the 134 municipalities with $5 \%$ or more of area with forest plantations, the results suggest that: i) PVS/GDP: maintaining all other variables constant, an increase of $1 \%$ in PVS/GDP is estimated to increase by an average of $0.42 \%$ in GAV Agri/GDP; this result shows that silviculture revenues generates improvement in the added value of the agriculture of these municipalities;

ii)GAV IndServ/GDP: maintaining all other variables constant, an increase of $1 \%$ in GAV IndServ/GDP is estimated to increase by an average of $1.43 \%$ in GAV Agri/GDP; this result shows that cities with higher added value of other sectors (industry and services) are related to the agricultural sector. This can be explained by the fact that many cities and regions that own forest plantations are also nearby and/or have steel poles that use charcoal or also pulp and paper, sawmills, etc.;

iii) ITR/GDP: maintaining all other variables constant, an increase of $1 \%$ in ITR/GDP is estimated to increase 
by an average of 70.1\% in GAV Agri/GDP; this result is explained by the fact that municipalities with vast areas destined to agroforestry production should have higher ITR collection.

In addition, the value of PVS/GDP standardized coefficient (0.401) which was higher than the others, means that the greatest impact on the variation of gross added value of agriculture is caused by the production value of silviculture, corroborating the initial expectations of the importance of the sector in finance of this group of cities.

It is important to emphasize that the results obtained from statistical procedures are exclusively related to the impacts on public finance and municipal revenues/tax collection. In order to have a correct addressing of socioeconomic issues, new social and economic information of the municipalities should be added to the analysis seeking for a more reliable analysis of the influence of forestry activity on the local economy and, especially, on the variables: income, education, job creation, health, quality of life, among others (Giambiagi and Além, 2008).

Therefore, although it can be concluded that forestry sector has contributed to the increase in revenues and to the improvement of the finance structure of municipalities with larger area for forest plantations in the period 2008-2013, it cannot be affirmed that this increase was accompanied by social improvements and socioeconomic transformations. Qualitative studies should be made for each district in the state considering their specificities and their degree of development, which may influence new policies for the forest sector.

Cajazeiras et al. (2011), for example, have demonstrated that eucalyptus plantations in Bahia state has led to improvements in the economic indicators analyzed in forest producing municipalities. However, the authors cited that such indicators may cover up problems such as the exodus generated by the decrease of jobs in rural areas and the increase of services in urban areas.

In this line, Ribeiro et al. (2017) pointed out that competition for land use among forest monocultures and agricultural production may lead to a poor spatial distribution of productive resources and greater economic dependence on regions of a single sector. The authors understand that alternatives to achieve a better land distribution and its productive resources constitute the use of productive forest properties in marginal agriculture areas, as well as the implementation of agroforestry systems, which can make feasible the integration of food production and rural development.

\section{CONCLUSION}

This work concluded that, for the period 20082013 and for the 134 municipalities with 5\% or more of forestry area: there was a linear relationship between the production value of silviculture and the ITR collection with the gross added value of agriculture. And there was greater participation of forestry revenues over GDP and per capita factor for these municipalities.

Moreover, for the same period and for municipalities with $10 \%$ or more of forestry area: there was an improvement in the Tax and Economic Development Index (IDTE).

These results demonstrated that planted forest sector contributed to the revenues structure, to tax collection and to GDP improvement of the municipalities with largest relative area of forestry.

For new studies, besides to the perspective of municipal finances, issues related to socioeconomic development must be observed, such as job creation, improvement in the well-being of rural and urban population, advances in local infrastructure, health, etc.

\section{ACKNOWLEDGEMENTS}

To the National Research Council/National Council for Scientific and Technological Development (CNPq) and to the Federal University of Viçosa.

\section{REFERENCES}

Almeida TM, Moreau AMSS, Moreau MS, Pires MM, Fontes EO, Góes LM. Reorganização socioeconômica no extremo sul da Bahia decorrente da introdução da cultura do eucalipto. Sociedade e Natureza. 2008;20(2):5-18.

Bresser-Pereira LC. Crescimento e desenvolvimento econômico. São Paulo: FGV: EESP;2006.(Texto para discussão,157).

Cajazeiras JER, Barbieri JC, Silva D. Estudo da sustentabilidade regional da produção industrial de eucalipto e seus impactos em sua região de influência. Revista da Micro e Pequena Empresa. 2011;1(2):17-33.

Revista Árvore. 2018;42(3):e420303 
Giambiagi F, Além AC. Finanças públicas: teoria e prática no Brasil. $3^{\text {a }}$.ed. Rio de Janeiro: Campus; 2008.

Gujarati DN, Porter DC. Econometria básica. $5^{\mathrm{a}}$ ed. Porto Alegre: Bookman; 2011.

Gurgel HC, Hargrave J, França F, Holmes RM, Ricarte FM, Dias BFS. Unidades de conservação e o falso dilema entre conservação e desenvolvimento. Boletim Regional Urbano e Ambiental. 2009;3:109-19.

Hair JF, Black WC, Babin BJ, Anderson RE, Tatham RL. Análise multivariada de dados. Porto Alegre: Bookman; 2005.

Harnett DL, Murphy JL. Introductory statistical analysis. $2^{\mathrm{a}}$ ed. Menlo Park: Addson-Wesley; 1976. 524p.

Hummel AC. Fortalecimento do Setor Florestal no Brasil. Brasília, DF: 2013.

Indústria Brasileira de Árvores - IBÁ. Relatório Anual. Brazilian Tree Industry. 2016;53(9):100.

Instituto Brasileiro de Geografia e Estatística. IBGE. Produção da Extração Vegetal e da Silvicultura - PEVS. 2015;30:1-48.

Ioannides YM, Overman HG. Zipf's law for cities: An empirical examination. Regional Science and Urban Economics. 2003;33(2):127-37.

Machado EF. O IDH e as atividades de plantio de florestas. Brasília, DF: Ministério do Meio Ambiente; 2004.

Maroco J. Análise estatística com utilização do SPSS. $3^{a}$ ed. Lisboa: Sílabo;2007.

Massardi W, Ferreira MAM, Faroni W. Impacto da contribuição de melhoria sobre a situação financeira de municípios brasileiros. Revista de Administração da UEG, 2014;5: 58.

Oliveira FADE, Virgínia I, Biondini F. Idte/ : Um Índice de Finanças para a Análise do Desenvolvimento - O caso dos Municípios de
Minas Gerais. Revista Brasileira de Administração Pública.2013;6(1):33-55.

Pestana MH, Gageiro JN. Análise de dados para ciências sociais a complementaridade do SPSS. $4^{a}$ ed. Lisboa: Sílabo; 2008.

Rezende JLP, Oliveira AD, Rodrigues C. Efeito dos tributos no custo de produção, na rotação e na reforma de Eucalyptus spp . Cerne. 2005;11(1):70-83.

Ribeiro GBD, Isbaex C, Valverde SR. Produção de biomassa florestal para energia em sistemas agroflorestais. Pesquisa Florestal Brasileira. 2017;37(92):605-18.

Secretaria do Tesouro Nacional. Prefeituras. Contas Anuais. FINBRA. [acessado em: 18 de out. 2016]. Disponível em: http://

www.tesouro.fazenda.gov.br/pt_PT/contas-anuais.

Silva SLP, Faroni W, Barbiéri RS. Ciclos políticoorçamentários e reeleição/: um estudo para os municípios do Norte do Brasil. Revista Científica da Faminas. 2011;7(1):99-120.

Stokes ME, Davis CS, Koch GG. Categorical Data Analysis Using the SAS System. $2^{\text {nd }}$. ed. Cary, NC: SAS Institute; 1990.

Valverde SR, Mafra JWA, Miranda MA, Souza CS, Vasconcelos DC. Silvicultura brasileira oportunidades e desafios da economia verde. Brasília, DF: FBDS; 2012.39p.

Valverde SR, Rente J, Valverde E. Estratégias e mecanismos de abastecimento da indústria de base Florestal. SEBRAE; 2014.

Vital BR, Carneiro AC, Pereira BL. Qualidade da madeira para fins energéticos. In: Santos F, editor. Bioenergia e Biorrefinaria: cana de açúcar e espécies florestais. Viçosa, MG: 2013. p.322-54.

Zhang D, Stenger A, Harou PA. Policy instruments for developing planted forests: Theory and practices in China, the U.S., Brazil, and France. Journal of Forest Economics. 2015;21(4):223-37. 